Article

\title{
The Impact of Changes in Species Richness and Species Replacement on Patterns of Taxonomic Homogenization in the Carpathian Forest Ecosystems
}

\author{
Tomasz Durak ${ }^{1, *}$, Roma Durak ${ }^{2}$, Ewa Węgrzyn ${ }^{3}$ and Konrad Leniowski ${ }^{3}$ \\ Received: 29 July 2015; Accepted: 13 November 2015; Published: 30 November 2015 \\ Academic Editors: Brian J. Palik and Eric J. Jokela \\ 1 Department of Botany, University of Rzeszów, ul. Zelwerowicza 4, Rzeszów PL-35-601, Poland \\ 2 Department of Invertebrate Zoology, University of Rzeszów, ul. Zelwerowicza 4, \\ Rzeszów PL-35-601, Poland; rdurak@ur.edu.pl \\ 3 Department of Zoology, University of Rzeszów, ul. Zelwerowicza 4, Rzeszów PL-35-601, Poland; \\ songbird.ewa@gmail.com (E.W.); songbird.konrad@gmail.com (K.L.) \\ * Correspondence: tdurak@ur.edu.pl; Tel.: +48-17-872-10-00; Fax: +48-17-872-12-65
}

\begin{abstract}
The Carpathians are Eastern Europe's largest contiguous forest ecosystem and a hotspot of biodiversity. However, not much is known about changes in species diversity in these forests. Here we investigate the long-time changes in the diversity of plant communities in the Eastern Carpathian beech forests. We also inquire about the similarity of plant communities between managed and protected forests. We conduct our analyses using not only the broad-sense measure of changes in $\beta$ diversity $\left(\beta_{\text {sor }}\right)$ but also the measures that reveal whether the changes result from spatial turnover $\left(\beta_{\text {sim }}\right)$ or nestedness $\left(\beta_{\text {nes }}\right)$. Our study demonstrated that the mean species richness did not significantly change over time in both forest types. However, we found a significant decrease of species diversity in protected forests and the same trend, but on a smaller scale, in managed forests. In both forest types the decrease of species diversity was mainly caused by spatial turnover, while nestedness-related changes were relatively small. However, the direction of changes in $\beta_{\text {nes }}$ differed in managed and unmanaged forests in such a way that it reduced the decrease of species diversity in managed forests and amplified the decrease of species diversity in unmanaged forests. We discuss our findings in terms of biotic homogenization.
\end{abstract}

Keywords: beta diversity partitioning; herb layer; East Carpathians Biosphere Reserve; beech forests

\section{Introduction}

The changes in species composition and diversity are widespread in nature [1]. In most ecosystems, depending on population dynamics and the current set of multiple disturbances, species diversity increases or decreases. The average species composition rarely reaches a steady-state equilibrium [2]. Changes in species diversity and the direction of such changes (increase/decrease) are natural processes, and as such cannot be treated as positive or negative ones. For example, natural succession in forest plant communities often involves a decrease in species diversity during the establishment phase of colonization and an increase in species diversity during steady-state phases [3].

However, beside natural disturbances, which are important forces in maintaining species diversity, forest ecosystems are also subjected to human impacts, often resulting in biotic homogenization [4]. Human-induced environmental changes may decrease habitat suitability for a high number of species, at the same time increasing the suitability for a limited number of biotas better adapted to anthropogenic altered habitats. The process of continuing replacement of 
native specialists by generalists or nonindigenous, locally expanding species is rapidly increasing the similarity of species composition [5-7]. As the stability of ecosystems in the face of disturbances may be positively related to the diversity in these ecosystems [8], biotic homogenization is perceived as a global problem.

The beech forest is one of the major forest types in Europe [9,10], and thus, understanding ecological processes in this woodland is very important. Despite the fact that the Carpathians are Eastern Europe's largest contiguous forest ecosystem and a hotspot of biodiversity [11,12], not much is known about long-term changes in the diversity of plant communities in these beech forests. Studies have focused on species diversity changes observed in the beech forests of Western and Northern Europe (reviewed in [10]). The conclusions of these studies cannot be generalized and applied to Eastern Carpathian beech forests for several reasons. First, forests in Western and Northern Europe have been subjected to higher environment pollution than the Eastern Carpathian woodlands [13,14]. They have also been more intensively timber-harvested, which considerably affected the forest structure and biodiversity [15,16]. Also, the forests in Western and Northern Europe have been exploited for a considerably longer time (some of them since the Roman Empire) than the Eastern Carpathian forests [17]. This resulted in both severe clearance and forest plantation of the former and a lower level of human-induced disturbance in the latter woodlands. There are not many primeval beech forests left in Western Europe and habitat fragmentation is a common issue [14]. In contrast, the Eastern Carpathian ancient beech forests are a precious ecosystem which constitutes the East Carpathian Biosphere Reserve (1992, ECBR). They are home to many endangered species, which are threatened with extinction or are no longer present in Western Europe. Many of them are iconic and/or the International Union for Conservation of Nature (IUCN) Red Listed animals and plants [18]. Thus, understanding the long-term changes and the differences in the diversity of plant communities between managed and protected forests will help to maintain their uniqueness.

Because forests are dynamic mixtures of habitats over time and across landscapes, the spatio-temporal analyses of changes in species diversity provide a useful diagnostic tool. We use such an approach in the present paper. The availability of past datasets enabled us to analyze and describe long-time changes in the understory vegetation of two beech forests in the Carpathian Mountains in Poland using re-inventory data based on semi-permanent plots. Moreover, in one of the forests, a part of the plots have received no forest management after the first inventory as it came under protection in 1973 and now it constitutes the Bieszczady National Park. This created an opportunity to inquire whether long-term protection resulted in different patterns of changes in species diversity than those observed in managed forests. The aim of our study was to investigate the changes in the diversity of plant communities in the Eastern Carpathian beech forests over the periods of 30 and 50 years. We also inquired about the similarity of plant communities between managed and unmanaged (protected) forests.

According to the intermediate disturbance hypothesis, which argues that species diversity is maximum at intermediate disturbance levels [19], one may expect that species diversity will decrease with decreasing disturbances. Thus, in case of the protected area, which recovers from human-induced disturbances, a decrease in species diversity may occur as a natural process. Similar trends may be observed in managed forests due to the gradual introduction of more sustainable management during the last decades. We addressed the above issues by testing the following hypotheses: (i) diversity of plant communities decreased over a long time-period in the Eastern Carpathian beech forests and (ii) patterns of changes in diversity of plant communities were different in managed and unmanaged forests. We also demonstrated that the partition of data, taking into account those two distinct methods of forest use, revealed patterns of changes in diversity that were vague on the pooled analysis. 


\section{Material and Methods}

\subsection{The Site of Study and Data Collection}

In this study we used two datasets collected from the Polish part of the Eastern Carpathians. The first dataset was obtained from sampling plots located in the Western Bieszczady Mountains (WBM, $1560 \mathrm{~km}^{2}$, maximum altitude $1346 \mathrm{~m}$ above sea level (a.s.l.), $49^{\circ} 03^{\prime} \mathrm{N}-49^{\circ} 21^{\prime} \mathrm{N}, 22^{\circ} 05^{\prime} \mathrm{E}-22^{\circ} 47^{\prime} \mathrm{E}$ ). The second dataset was collected on the adjacent, more northern part of the Eastern Carpathians and covered the majority of the area of the Sanocko-Turczanskie Mountains (S-TM, approx. $460 \mathrm{~km}^{2}$, maximum altitude of $672 \mathrm{~m}$ a.s.l., a part of the Natura 2000 protection program, Słonne Mountains PLH180013, PLB180003, $49^{\circ} 25^{\prime} \mathrm{N}-49^{\circ} 38^{\prime} \mathrm{N}, 22^{\circ} 10^{\prime} \mathrm{E}-22^{\circ} 30^{\prime} \mathrm{E}$ ). The investigated montane region is built of flysch, which consists mainly of sandstone. The main types of soils are brown soils: Eutric Cambisols (brown soils leached and gleyed) and Dystric Cambisols (acid brown soils) [20,21]. The mean annual temperature and precipitation are $5.2{ }^{\circ} \mathrm{C}$ and $1100 \mathrm{~mm}$ in WBM and $7.3^{\circ} \mathrm{C}$ and $814 \mathrm{~mm}$ in S-TM areas [22,23]. The area is characterized by a high forest cover $(c a .70 \%)$. The montane zone is mainly covered by the fertile Carpathian beech forest (dominated by Fagus sylvatica L.) with a fir (Abies alba Mill.) and sycamore (Acer pseudoplatanus L.) admixture (phytosociological association Dentario glandulosae-Fagetum (D.g.-F)) [20,24].

There are four phytosociological units within the analyzed fertile Carpathian beech forest, assigned along the gradient of nutrient availability, moisture, and soil $\mathrm{pH}$ : D.g.-F. festucetosum drymeiae on the driest, most acidic, and nutrient-poor soils; D.g.-F. typicum and D.g.-F. lunarietosum on intermediate soil conditions; and D.g.-F. allietosum ursinii on the moist and most fertile sites with a slightly acidic or slightly alkaline $\mathrm{pH}$. They represent the whole range of habitat conditions present in the montane forest zone in this part of the Carpathians [20,25].

Over the past 200 years forest management practices in the study area underwent significant changes. Due to an intense and unsustainable exploitation combined with an increase in human population, the forest covered only $30 \%-40 \%$ of the area in the 19th and at the beginning of the 20th centuries [26]. Due to forced resettlements after World War II (WWII), the density of the local population drastically dropped. In those years, forest stands often had a uniform age structure and an average age of 40-60 years [25]. After the socio-economic changes of the 1990s, an emphasis was placed on sustainable forest management. This was mainly achieved by substituting the uniform shelterwood system (the main management system since WWII) with the irregular shelterwood system. Additionally, in the mid-20th century, the common practice of traditional non-timber forest use by the locals, such as firewood and litter raking or wood pasture, disappeared [27,28]. A part of the forests in the WBM area came under protection in 1973 and now it constitutes the Bieszczady National Park. The WBM and S-TM areas are a part of the Eastern Carpathian Biosphere Reserve (1992, ECBR). Based on the data obtained from the State Forestry administration and the authorities of the Bieszczady National Park, the average age of the majority of forest stands in the S-TM and WBM sampling areas exceeded 100 years in the 2000s.

We used two datasets obtained by the repeated sampling of semi-permanent plots. The first dataset (62 plots, 50 years between samplings) characterized the beech forest in the WBM area between 1955-1962 and 2005-2008 (from here on assigned as 1950s and 2000s). The second dataset (66 plots, 30 years between samplings) collected in the area of S-TM between 1972-1973 and 2005-2007 (from here on assigned as 1970s and 2000s) enabled the analysis of changes occurring in the S-TM forests.

Phytosociological databases collected since the early 20th century are an important source of ecological information as they enable us to study long-term spatio-temporal changes in ecosystems. The weak point of such databases is that different researchers may determine the plots somewhat subjectively, which may bias the results and does not show the real differentiation of vegetation $[29,30]$. Additionally, the analyses may be burdened with an error resulting from the imprecise locating of past inventories. However, our datasets depicted full variability of investigated 
beech forest vegetation and we put an effort into the exact repetition of sampling. Thus, we assume observer's bias, which seems unavoidable, may play some role but does not account for a significant error.

For both study areas, sampling plots were located based on the data from archive phytosociological documents $[20,25]$ and the sampling was repeated. In the case of the S-TM area, the plots were located with the use of a 1:45,000 scale unpublished map, drawn by Dzwonko during his study; for the WBM area, the plots were located with the use of coarse coordinates and a small-scale map published by Zarzycki [25]. To make the newly obtained datasets comparable with the old ones, the same sampling method (Braun-Blanquet approach, [31]) was used and the conditions such as the size of the sampling plot (in most cases between 200 and $500 \mathrm{~m}^{2}$ in WBM and 200 or $400 \mathrm{~m}^{2}$ in S-TM), topography (altitude above sea level, exposure, and slope), and time of the year were matched with those described in the original reports by Dzwonko [20] and Zarzycki [25]. It was difficult to locate the same plots precisely; however, our plots were not more than $50 \mathrm{~m}$ away from the plots of Dzwonko [20] and, at last, in the same forest vegetation patches investigated by Zarzycki [25]. Thus, we assume that differences between the two samples in the species composition reflected real changes that took place in the studied forests.

According to the species-area theory, the number of species increases along with the sampled area. Consequently, differences in species composition between the two plots of different size may result from differences in each plot area. However, we found no significant correlation between species richness and plot size in the S-TM dataset (mean number of species $=25.14$ on plots $200 \mathrm{~m}^{2}$ and 21.65 on plots $\left.400 \mathrm{~m}^{2}\right)$ and even a weak negative correlation in the WBM dataset $\left(r_{s}=0.28, p=0.27\right.$, mean number of species $=28.65$ on plots $200-300 \mathrm{~m}^{2}$ and 27.08 on plots $\left.400-500 \mathrm{~m}^{2}\right)$. It demonstrates that larger plots do not consist of higher numbers of species. Thus, we made the assumption that the potential methodological bias resulting from using plots of different size did not affect the results of our study.

The sampling plots from the 1950s and 1970s were located in the area under active forest management. Due to the conversion of the best-preserved forests of WBM into a protected area in 1973, 32 of 62 plots from the 1950s were included in the protected forests, from here on termed 'unmanaged' forests. As a consequence the dataset from the WBM area was divided into managed ( 30 plots) and unmanaged forests (32 plots). Our analyses concerned species composition (presence-absence data) of the herbaceous layer (including ferns and flowering plants and excluding tree seedling and bryophytes), which is the most disturbance-sensitive and diverse plant community in forests [32].

\subsection{Data Analysis}

In order to quantify biotic homogenization, changes in the taxonomic similarity were analyzed with pairwise dissimilarity indices between the two sampling periods for each dataset (WBM and S-TM forests). We used three $\beta$ diversity indices:

(1) Sorensen's dissimilarity index $\left(\beta_{\text {sor }}\right)$, which measures dissimilarity in species composition between sites due to both spatial turnover and differences in species richness [33],

(2) Simpson's dissimilarity index $\left(\beta_{\text {sim }}\right)$, which expresses spatial turnover without the influence of richness gradients,

(3) nestedness-resultant dissimilarity index $\left(\beta_{\text {nes }}\right)$, which expresses compositional differences in richness caused by nestedness.

Using $\beta_{\text {sim }}$ and $\beta_{\text {nes }}$ allowed us to demonstrate not only general changes in the diversity of plant communities but also more subtle patterns of these changes [33]. A difference between a spatial turnover and nestedness lies in the fact that turnover implies the replacement of some species by others, while nestedness occurs when species of one site are the subset of the species of another (richer) site. Thus, nestedness mostly implies a species extinction in the species-poor site without 
the replacement of the lost species by other ones [33]. As both processes (species replacement and species extinction) may lead to the decrease of the diversity of plant communities and the increase of homogenization, it seems reasonable to analyze them separately.

Sorensen's dissimilarity index [34] was calculated according to the equation:

$$
\beta_{\text {sor }}=\frac{b+c}{2 a+b+c}
$$

For this and further equations, $a$ denotes the number of species common for the two sampling plots, $b$ indicates the number of species only occurring in the first sampling plot of the pair, and $c$ denotes the number of species occurring only in the second sampling plot of the pair.

Simpson's dissimilarity index was calculated using the equation $[35,36]$ :

$$
\beta_{\text {sim }}=\frac{\min (b, c)}{a+\min (b, c)}
$$

Nestedness-resultant dissimilarity index was calculated using the equation [33]:

$$
\begin{aligned}
\beta_{\text {nes }}=\beta_{\text {sor }}- & \beta_{\text {sim }}=\frac{b+c}{2 a+b+c}-\frac{\min (b, c)}{a+\min (b, c)} \\
& =\frac{\max (b, c)-\min (b, c)}{2 a+\min (b, c)+\max (b, c)} \times \frac{a}{a+\min (b, c)}
\end{aligned}
$$

We analyzed the data using two different approaches: (i) among-plot dissimilarity between the two surveys and (ii) within-plot compositional shifts over time, following a method adapted from Baeten et al. [37].

In the first approach, our analyses of biotic homogenization were based on the most frequently used comparison of mean values of pairwise dissimilarity indices between temporal censuses. This method is largely equivalent to the measure of $\beta$ diversity proposed by Anderson et al. $[38,39]$. To do it we calculated average interplot dissimilarities (for each plot the mean of the pairwise dissimilarities against all other plots in terms of $\beta_{\text {sor }}, \beta_{\text {sim }}$, and $\beta_{\text {nes }}$ ). The changes in plot taxonomic similarity were tested by comparing the mean values of dissimilarities ( $\beta_{\mathrm{sor}}, \beta_{\mathrm{sim}}$, and $\beta_{\mathrm{nes}}$ ) of each plot between past and present inventory using a paired t-test with a bootstrap procedure $(n=10,000)$.

In the second approach we used the NMDS (nonmetric multidimensional scaling) on the full data matrix (i.e., the data of the past and present inventory) for each forest to demonstrate changes in all $\beta$ indices on the plot level. For each studied forest (S-TM, WBM, WBM managed, and WBM unmanaged) we created three dissimilarity matrices based on the three dissimilarity measures $\left(\beta_{\text {sor }}\right.$, $\beta_{\text {sim }}$, and $\left.\beta_{\text {nes }}\right)$. These matrices were used for the ordination of plots. Next, vectors indicating mean shifts between sampling periods were created. This was achieved by running the NMDS analysis until a stable result was obtained. This stable result was then used as the final result of the analysis. Based on the analysis of the stress value against the number of dimensions (scree test) and the clarity of the final configuration of the NMDS, we used two axes in the case of the $\beta_{\text {sor }}, \beta_{\text {sim }}$ matrix and one axis in the case of the $\beta_{\text {nes }}$ [40]. The significance of directional shifts between the pairs of sampling plots from two sampling periods was assessed using a permutational multivariate analysis of variance (PERMANOVA) [41].

All statistical analyses were carried out in the "vegan" 2.0 package (by Oksanen J, Oulu, Finland) [42] and "tanova" package (Wing Wong's lab \& Stanford Genome Technology Center-Stanford University, Stanford, CA, USA) [43] of R statistical language (R Foundation for Statistical Computing, Vienna, Austria) [44] and PAST 2.17 [45].

\section{Results}

Altogether 180 plant species of the herbaceous layer were found in the study area, including past (1950s and 1970s) and present (2000s) inventories. Of these species, 113 occurred both in the 
past and at present. Forty-seven species recorded in the past were lost and 20 new species were gained in the 2000s. The highest loss in the number of species occurred in the WBM forest (Table 1). The largest difference between the number of species lost and gained occurred in unmanaged WBM forests ( 29 species) and the smallest in the S-TM forest (three species). Approximately $16 \%$ of the total number of species disappeared and 19\% was gained (Table 1).

Table 1. A comparison of the species pool of the two surveys in the Sanocko-Turczanskie Mountains and the Western Bieszczady Mountains: the overall number of species recorded in the two surveys, species present in both surveys, species lost or gained between the 1950s/1970s and 2000s.

\begin{tabular}{|c|c|c|c|}
\hline Total Pool of Species & No. of Stable Species & $\begin{array}{l}\text { No. of Lost Species } \\
\text { (\% of Total Pool) }\end{array}$ & $\begin{array}{l}\text { No. of Gained Species } \\
\text { (\% of Total Pool) }\end{array}$ \\
\hline \multicolumn{4}{|c|}{ S-TM-managed forest } \\
\hline 133 & 86 & $22(16.5)$ & $25(18.8)$ \\
\hline \multicolumn{4}{|c|}{ WBM-whole forest } \\
\hline 153 & 91 & $46(30.1)$ & $16(10.5)$ \\
\hline \multicolumn{4}{|c|}{ WBM-managed forest } \\
\hline 126 & 75 & $38(30.2)$ & $13(10.3)$ \\
\hline \multicolumn{4}{|c|}{ WBM-unmanaged forest } \\
\hline 128 & 81 & $38(29.7)$ & $9(7.0)$ \\
\hline
\end{tabular}

Mean sampling plot species richness in the investigated area was 25 species, both in the past (1950s-1970s) and at present (2000s). The highest number of species was recorded in sampling plots of managed WBM forests (on average 28 species in the 1950s and 27 species in the 2000s). We did not find any significant changes in the mean species richness in forests in the S-TM and WBM areas (Figure 1). However, the decrease in species richness in unmanaged WBM forests was near-significant (Figure 1).

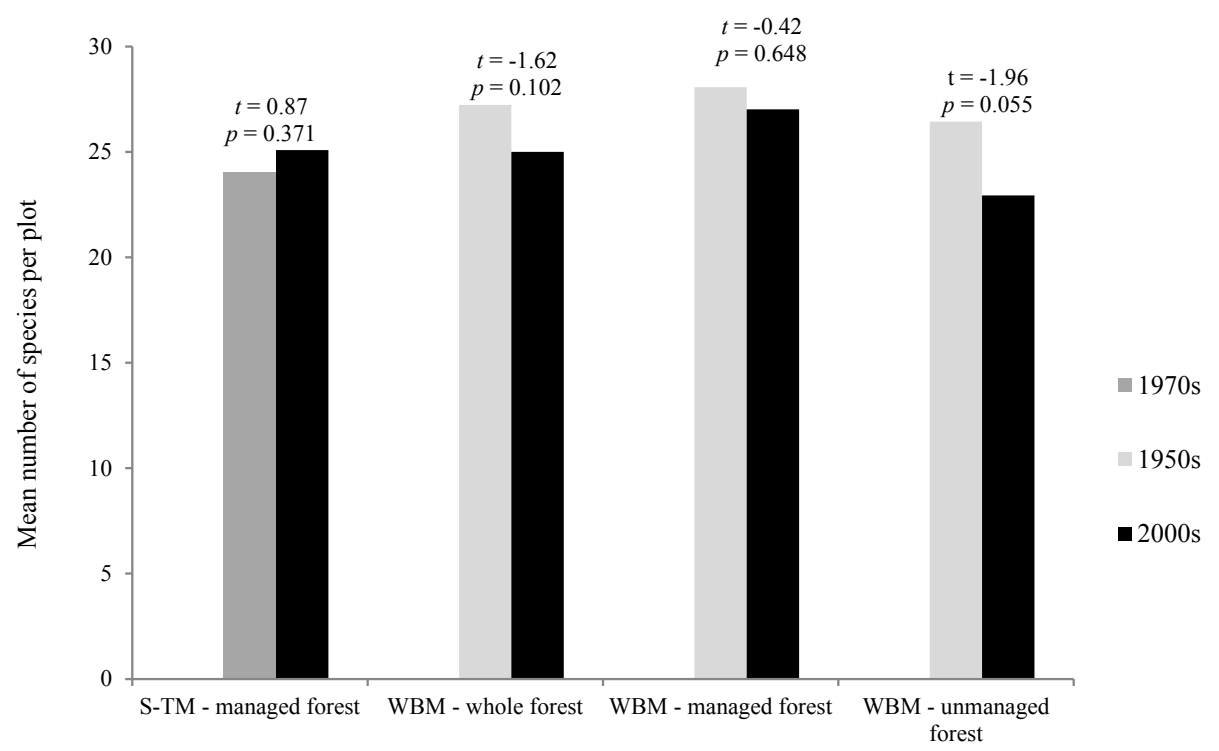

Figure 1. Changes in species richness in the Sanocko-Turczanskie Mountains and the Western Bieszczady Mountains. S-TM-managed forest: $n=66$; WBM-whole forest: $n=62$; WBM-managed forest: $n=30$; WBM-unmanaged forest: $n=32$ (paired t-test with bootstrap procedure $(n=10,000)$ ).

A comparison of the past and present species richness in the S-TM and WBM forests suggests that species richness decreased in species-rich plots and increased in species-poor plots in WBM unmanaged forests (Figure 2a). The species richness gradient decreased in unmanaged WBM forests and slightly increased in both managed forests (Figure 2). 

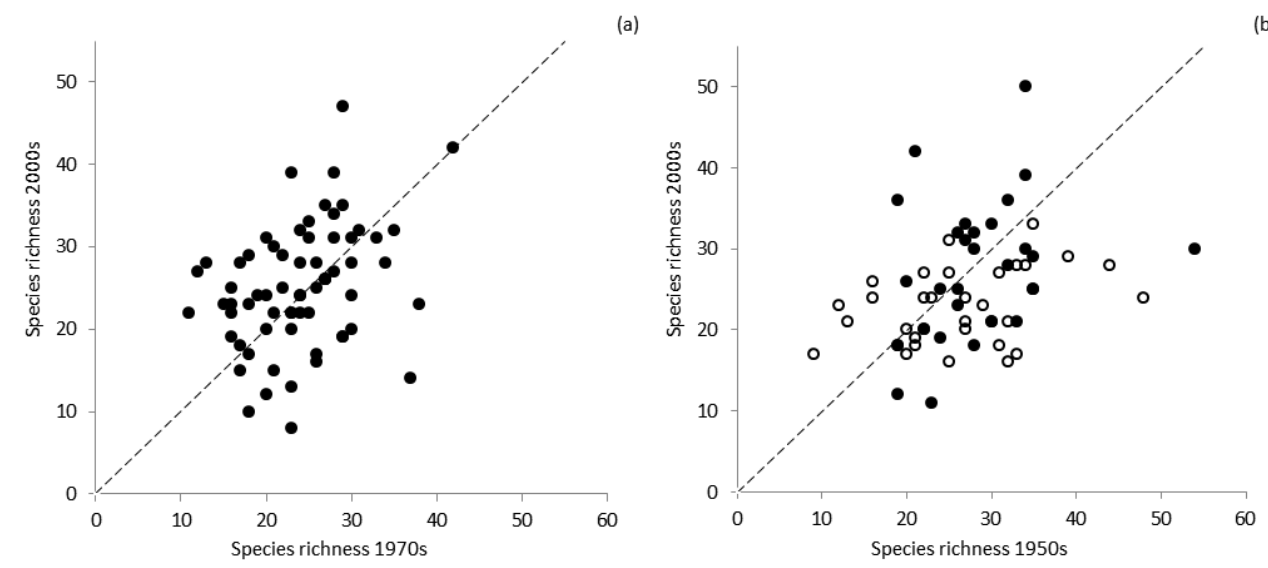

Figure 2. Past and present species richness of sampling plots. The dashed lines present a hypothetical situation in which the sampling plots had the same numbers of species between the two surveys. (a) Forest in the Sanocko-Turczanskie Mountains; (b) forest in the in the Western Bieszczady Mountains; filled circles: managed; open circles: unmanaged forests.

According to Sorensen's dissimilarity index $\left(\beta_{\text {sor }}\right)$ the highest species diversity decrease occurred in unmanaged WBM forests, while in managed forests it was either small (S-TM forests) or insignificant (managed WBM forests) (Table 2). Most of the changes in the broad-sense species diversity $\left(\beta_{\text {sor }}\right)$ were explained by $\beta_{\text {sim }}$, while $\beta_{\text {nes }}$ accounted for relatively small changes in all studied forests. Our results showed that $\beta_{\text {sim }}$ decreased significantly in all cases but the direction of changes in $\beta_{\text {nes }}$ differed between forest types. In both managed forests $\beta_{\text {nes }}$ increased and in the unmanaged forest it decreased (Table 2). Due to the additive effect of decreasing $\beta_{\text {sim }}$ and $\beta_{\text {nes }}$ in the unmanaged WBM forest, the overall species diversity decrease $\left(\beta_{\text {sor }}\right)$ was the highest in this type of the forest. The combined analysis of all WBM data (from managed and unmanaged forests) blurred the differences in changes in $\beta_{\text {nes }}$ (Table 2). This sheds some light on the importance of analyzing differently managed forests separately.

Table 2. The mean values of species diversity for the first and second inventory and the changes in species composition dissimilarity in the investigated part of the Sanocko-Turczanskie Mountains and the Western Bieszczady Mountains between the 1950s/1970s and 2000s in managed and unmanaged forests. S-TM-managed forest: $n=66$; WBM-whole forest: $n=62$; WBM-managed forest: $n=30$; WBM-unmanaged forest: $n=32$ (paired t-test with bootstrap procedure $(n=10,000)$ ).

\begin{tabular}{|c|c|c|c|c|c|}
\hline & Mean Value in the Past & Mean Value at Present & Mean Index Change & $t$ & $p$ \\
\hline & $1950 \mathrm{~s} / 1970 \mathrm{~s}$ & $2000 s$ & $\Delta \beta$ & & \\
\hline \multicolumn{6}{|c|}{ S-TM-managed forest } \\
\hline$\beta_{\text {sor }}$ & 0.51 & 0.48 & -0.03 & -2.4 & 0.0180 \\
\hline$\beta_{\text {sim }}$ & 0.43 & 0.38 & -0.05 & -3.61 & 0.0001 \\
\hline$\beta_{\text {nes }}$ & 0.09 & 0.11 & 0.02 & 3.69 & 0.0002 \\
\hline \multicolumn{6}{|c|}{ WBM-whole forest } \\
\hline$\beta_{\text {sor }}$ & 0.52 & 0.45 & -0.08 & -15.4 & 0.0001 \\
\hline$\beta_{\text {sim }}$ & 0.44 & 0.34 & -0.09 & -7.69 & 0.0001 \\
\hline$\beta_{\text {nes }}$ & 0.09 & 0.10 & 0.02 & 2.8 & 0.0050 \\
\hline \multicolumn{6}{|c|}{ WBM-managed forest } \\
\hline$\beta_{\text {sor }}$ & 0.47 & 0.44 & -0.03 & -1.78 & 0.0770 \\
\hline$\beta_{\text {sim }}$ & 0.40 & 0.32 & -0.08 & -4.32 & 0.0001 \\
\hline$\beta_{\text {nes }}$ & 0.08 & 0.12 & 0.05 & 4.24 & 0.0001 \\
\hline \multicolumn{6}{|c|}{ WBM-unmanaged forest } \\
\hline$\beta_{\text {sor }}$ & 0.55 & 0.42 & -0.12 & -7.12 & 0.0001 \\
\hline $\begin{array}{l}\beta_{\text {sor }} \\
\beta_{\text {sim }}\end{array}$ & 0.45 & 0.35 & -0.10 & -5.47 & 0.0001 \\
\hline$\beta_{\text {nes }}$ & 0.10 & 0.07 & -0.02 & -3.43 & 0.0010 \\
\hline
\end{tabular}


The NMDS analysis of changes in the species composition on the sampling plot level, based on $\beta_{\text {sor }}$ and $\beta_{\text {sim }}$, indicated marked plot-level compositional shifts between the past (1950s and 1970s) and present (2000s) plant communities (Table 3, Supplementary Figures S1 and S2). Changes in dissimilarity based on $\beta_{\text {sim }}$ and $\beta_{\text {nes }}$ of the pairs of sampling plots from the two sampling periods differed in managed and unmanaged forests. The compositional shifts on the sampling plot levels based on $\beta_{\text {sim }}$ were lower in unmanaged forests than in managed ones. On the other hand, compositional shifts on the sampling plot levels based on $\beta_{\text {nes }}$ were statistically significant only in the unmanaged forest.

Table 3. The significance of directional herb layer vegetation shifts between the pairs of sampling plots in the 1950s /1970s and 2000s in the Sanocko-Turczanskie Mountains and the Western Bieszczady Mountains. S-TM-managed forest: $n=66$; WBM-whole forest: $n=62$; WBM-managed forest: $n=30$; WBM-unmanaged forest: $n=32$ (PERMANOVA test).

\begin{tabular}{lcccccc}
\hline & \multicolumn{2}{c}{$\beta_{\text {sor }}$} & \multicolumn{2}{c}{$\beta_{\text {sim }}$} & \multicolumn{2}{c}{$\beta_{\text {nes }}$} \\
\cline { 2 - 7 } & $\boldsymbol{F}$ & $\boldsymbol{p}$ & $\boldsymbol{F}$ & $\boldsymbol{p}$ & $\boldsymbol{F}$ & $\boldsymbol{p}$ \\
\hline S-TM-managed forest & 8.22 & 0.0001 & 4.09 & 0.0030 & 0.97 & 0.3936 \\
WBM-whole forest & 9.05 & 0.0001 & 9.56 & 0.0001 & 1.76 & 0.1500 \\
WBM-managed forest & 3.47 & 0.0091 & 4.97 & 0.0020 & 1.75 & 0.1680 \\
WBM-unmanaged forest & 7.29 & 0.0001 & 4.93 & 0.0024 & 3.94 & 0.0130 \\
\hline
\end{tabular}

\section{Discussion}

The results of our study revealed that the mean species richness of the herb layer did not significantly change over time both in managed and unmanaged Eastern Carpathian beech forests. However, we observed a near-significant decrease of species richness in the latter woodlands, which indicates that the ecological processes in both forest types may slightly differ.

Despite no significant changes in species richness, our analyses of the herb layer vegetation structure revealed the significant decrease of species diversity in the unmanaged forest. The same trend, but on a smaller scale, was observed in managed forests. This finding confirms our hypothesis assuming that the diversity of plant communities decreased over a long time-period in the Eastern Carpathian beech forests. Whether or not the decrease in species diversity was a result of decreased human-induced disturbances is disputable because some other factors, for example forest aging, may have similarly affected species diversity. However, our study demonstrated that the highest decrease in species diversity occurred in the least human-disturbed protected forests. Thus, it seems plausible that the pronounced decrease of species diversity in Bieszczady National Park is a natural process of recovery from the past human-induced disturbances. This finding is consistent with results of surveys of German submontane beech forests at 10-year intervals [46].

Our study also inquired about the patterns of changes in the diversity of plant communities in managed and unmanaged forests. To date, analyses on changes in plant diversity have indicated that homogenization is the most frequent process occurring in the European forests [47-49]. In the majority of the studies addressing this issue, classical, 'broad-sense' Sorensen's beta diversity or Jaccard's dissimilarity indices were used. However, as demonstrated by Baeten et al. [37], if the more specific components of beta diversity, such as beta turnover and beta nestedness, are not discriminated, the actual patterns of changes in the species composition may be concealed. The results of our study revealed that both in managed and unmanaged forests the decrease of species diversity was mainly caused by non-random replacement of some species by others (spatial turnover), while nestedness-related changes were relatively small. However, the direction of changes in $\beta_{\text {nes }}$ differed in managed and unmanaged forests in such a way that it balanced $\beta_{\text {sim }}$ in the former but acted additively with $\beta_{\text {sim }}$ in the latter. As a result, nestedness-related changes in species diversity reduced the decrease of species diversity in managed forests and amplified the decrease of species diversity 
in unmanaged forests. Thus, our hypothesis assuming different patterns of changes in the diversity of plant communities in managed and unmanaged forests was confirmed by the results of our study.

The analysis of compositional shifts on the sampling plot level indicated that the main cause of homogenization in managed forests was the decrease in spatial turnover. In contrast, the changes in beta nestedness were not uniform-in some plots species richness increased over time, but in other ones it decreased. As a result of the above-mentioned processes, managed forests underwent homogenization and differentiation of the plant community simultaneously. This is in accordance with the results of an earlier study of the same forests [50]. In contrast, homogenization in unmanaged forests was caused not only by the decrease of turnover but also by the nestedness-related decrease in species richness. As a consequence, the species composition of the present sampling plots in unmanaged forests was a subset of the species composition of these plots sampled in the past. A similar pattern of homogenization was reported in a forest reserve in the UK [37].

There are various environmental drivers of change in plant community composition. In the Polish part of the Eastern Carpathians, these drivers were most likely related to the decrease in the intensity of forest use and forest aging [50-52], which resulted in a lower level of disturbances as well as an increase in the density of the canopy and the volume of the forest stand $[28,53,54]$. These factors most likely contributed towards higher habitat stability, which led to the decrease in species diversity.

In managed aging beech forests the accumulating litter hinders plant development and, combined with wood extraction by forestry, causes soil acidification. This especially affects the nutrient-poor beech forest communities [55,56], which naturally consist of a small number of species $[20,25]$. The above process may have caused a decrease in species richness in species-poor areas due to the extinction of the species demanding a higher soil $\mathrm{pH}$ and fertility (e.g., Corydalis cava Schweigg. and Körte, Paris quadrifolia L., Pulmonaria obscura Dumort.) $[50,57]$. At the same time species richness may have increased in species-rich areas, for example, due to the higher amount of nutrients available in more diverse stands. As presented by Durak and Holeksa [50], such conditions may favor the expansion of species with a wide soil $\mathrm{pH}$ range, and a strong ability to spread laterally and induce vegetative regeneration or regeneration by seeds/spores dispersed on long distans (e.g., Dryoperis dilatata (Hoffm.) A. Gray, Rubus idaeus L.). These processes were likely to trigger an increase in the species richness differences between plots, which in turn may have resulted in a decrease in nestedness at the community level.

The cessation of non-timber and forestry practices in the protected forests caused a significant decrease of disturbances, allowing the recovery of forest stands. The resulting increase in canopy closure contributed to a reduction in light availability at the forest floor [57]. It is also likely that the amount of coarse woody debris (considered as significant carbon and nutrient pools) increased, which may have improved the fertility of habitats [58-61]. According to the succession theory, the increase in the density of the canopy layer and the fertility of the forest habitats is concomitant with an increase in competition. Consequently, light-demanding species are likely to be replaced by the shade-tolerant ones (e.g., Epilobium montanum L. and Urtica dioica L. vs. Galeobdolon luteum Huds. and Lysimachoa nemorum L. [57]). Our findings also suggest that, due to the recovery of forest habitats, the plant species richness increased in the species-poor areas and it decreased in the species-rich forests. As a result, the diversity decreased.

According to Peet and Christensen [3], the diversity and species richness should increase in steady-state phases of forest stand development. Thus, the decline in species diversity and richness suggests that, despite 30 years of strict protection, Bieszczady National Park still represents a transitional phase of succession. In conclusion, our results indicated that plant diversity changes in time appeared to be related to forestry practices. In managed forests, plant diversity changes led to homogenization resulting from the turnover. However, it is also important to note that the process of homogenization occurred in parallel to the differentiation. In unmanaged protected forests, homogenization which occurred during forest habitat recovery was driven by both turnover and nestedness. Therefore, to fully disentangle and assess the impact of turnover and nestedness on 
vegetation diversity, future analyses should include the characteristics of the species-facilitating $\beta$ turnover and nestedness changes in the managed as well as the protected forests.

Acknowledgments: We would like to thank Professor Zbigniew Dzwonko for making original maps with the locations of archival phytosociological relevés available on subregion S-TM. We thank the authorities and staff of Bieszczady National Park for their kind cooperation and for granting permission to conduct our research in the park. We are grateful to the Regional Directorate of the State Forests in Krosno for granting the access to their management specification and administrative documentation. Financial support for this study was provided by the statutory fund of the University of Rzeszów.

We also kindly thank two anonymous referees for their helpful suggestions and comments on the manuscript.

Author Contributions: Tomasz Durak conceived, designed and implemented the study, performed data analysis and prepared the manuscript. Roma Durak contributed to field work. Ewa Wegrzyn contributed to manuscript preparation. Konrad Leniowski contributed to statistical analyses.

Conflicts of Interest: The authors declare no conflict of interest.

\section{References}

1. Vellend, M. Conceptual synthesis in community ecology. Q. Rev. Biol. 2010, 85, 183-206. [CrossRef] [PubMed]

2. Connell, J.H.; Slatyer, R.O. Mechanisms of succession in natural communities and their role in community stability and organization. Am. Nat. 1977, 111, 1119-1144. [CrossRef]

3. Peet, R.K.; Christensen, N.L. Changes in species diversity during secondary forest succession on the North Carolina piedmont. In Diversity and Pattern in Plant Communities; During, H.J., Werger, M.J., Eds.; SPB Academic Publishing: The Hague, The Netherlands, 1988; pp. 233-245.

4. Solar, R.R.D.C.; Barlow, J.; Ferreira, J.; Berenguer, E.; Lees, A.C.; Thomson, J.R.; Louzada, J.; Maués, M.; Moura, N.G.; Oliveira, V.H.F.; et al. How pervasive is biotic homogenization in human-modified tropical forest landscapes? Ecol. Lett. 2015, 18, 1108-1118. [CrossRef] [PubMed]

5. McKinney, M.L.; Lockwood, J.L. Biotic homogenization: A few winners replacing many losers in the next mass extinction. Trends Ecol. Evol. 1999, 14, 450-453. [CrossRef]

6. Olden, J.D.; Poff, N.L.; Douglas, M.R.; Douglas, M.E.; Fausch, K.D. Ecological and evolutionary consequences of biotic homogenization. Trends Ecol. Evol. 2004, 19, 18-24. [CrossRef] [PubMed]

7. Olden, J.D.; Rooney, T.P. On defining and quantifying biotic homogenization. Glob. Ecol. Biogeogr. 2006, 15, 113-120. [CrossRef]

8. Loreau, M. Biodiversity and ecosystem functioning: Recent theoretical advances. Oikos 2000, 91, 3-17. [CrossRef]

9. Bohn, U.; Gollub, G.; Hettwer, C.; Neuhäuslová, Z.; Raus, Th.; Schlüter, H.; Weber, H. Karte der Natürlichen Vegetation Europas/Map of the Natural Vegetation of Europe, Maßstab/Scale 1:2.500.000, Interaktive/Interactive CD-ROM-Erläuterungstext, Legende, Karten/Explanatory Text, Legend, Maps; Landwirtschaftsverlag: Münster, Germany, 2004.

10. Brunet, J.; Fritz, Ö.; Richnau, G. Biodiversity in European beech forests-A review with recommendations for sustainable forest management. Ecol. Bull. 2010, 53, 77-94.

11. Webster, R.; Holt, S.; Avis, C. The Status of the Carpathians. A Report Developed as a Part of The Carpathian Ecoregion Initiative; WWF: Vienna, Austria, 2001; p. 67.

12. Oszlányi, J.; Grodzińska, K.; Badea, O.; Shparyk, Y. Nature conservation in Central and Eastern Europe with a special emphasis on the Carpathian Mountains. Environ. Pollut. 2004, 130, 127-134. [CrossRef] [PubMed]

13. Grodzińska, K.; Szarek-Łukaszewska, G. Polish mountain forests: Past, present and future. Environ. Pollut. 1997, 98, 369-374. [CrossRef]

14. Rackham, O. Ancient woodlands: Modern threats. New Phytol. 2008, 180, 571-586. [CrossRef] [PubMed]

15. Hannah, L.; Carr, J.L.; Lankerani, A. Human disturbance and natural habitat: A biome level analysis of a global data set. Biodivers. Conserv. 1995, 4, 128-155. [CrossRef]

16. Bengtsson, J.; Nilsson, S.G.; Franc, A.; Menozzi, P. Biodiversity, disturbances, ecosystem function and management of European forests. For. Ecol. Manag. 2000, 132, 39-50. [CrossRef]

17. Kaplan, J.O.; Krumhardt, K.M.; Zimmermann, N. The prehistoric and preindustrial deforestation of Europe. Quat. Sci. Rev. 2009, 28, 3016-3034. [CrossRef] 
18. Witkowski, Z.J.; Król, W.; Solarz, W. Carpathian List of Endangered Species; WWF and Institute of Nature Conservation, Polish Academy of Sciences: Vienna, Austria; Krakow, Poland, 2003; p. 64.

19. Connell, J.H. Diversity in tropical rain forests and coral reefs. Science 1978, 199, 1302-1310. [CrossRef] [PubMed]

20. Dzwonko, Z. Communities of the Góry Słonne Range (Polish Eastern Carpathians). Fragm. Flor. Geobot. 1977, 23, 161-200.

21. Skiba, S.; Drewnik, M. Soil Map of the Polish Carpathian Mountains. Rocz. Bieszcz. 2003, 11, 15-20.

22. Michna, E.; Paczos, S. Zarys klimatu Bieszczadów Zachodnich; Ossolineum: Wrocław, Poland; Warszawa, Poland; Kraków, Poland; Gdańsk, Poland, 1972.

23. Nowosad, M. Outlines of climate of the Bieszczady National Park and its buffer zone in the light of previous studies. Rocz. Bieszcz. 1995, 4, 163-183.

24. Environment Protection in the Podkarpackie Voivodship in 2004-2006; Statistical Office in Rzeszów: Rzeszów, Poland, 2007.

25. Zarzycki, K. Lasy Bieszczadów Zachodnich. Acta Agrar. Silv. Ser. Silv. 1963, 3, 3-132.

26. Schramm, W. Lasy i Zwierzyna Gór Sanockich; Państwowe Wydawnictwo Naukowe: Poznań, Poland, 1958.

27. Glatzel, G. The Impact of historic land use and modern forestry on nutrient relations of Central European forest ecosystems. Fertil. Res. 1991, 27, 1-8. [CrossRef]

28. Kuemmerle, T.; Hostert, P.; Radeloff, V.C.; Perzanowski, K.; Kruhlov, I. Post-socialist forest disturbance in the Carpathian border region of Poland, Slovakia, and Ukraine. Ecol. Appl. 2007, 17, 1279-1295. [CrossRef] [PubMed]

29. Fischer, H.S.; Bemmerlein, F.A. An outline for data analysis in phytosociology: Past and present. Vegetatio 1989, 81, 17-28. [CrossRef]

30. Chytrý, M. Phytosociological data give biased estimates of species richness. J. Veg. Sci. 2001, 12, 439-444. [CrossRef]

31. Braun-Blanquet, J. Pflanzensoziologie, Grundzüge der Vegetationskunde; Springer-Verlag: Wien, Austria; New York, NY, USA, 1964.

32. Gilliam, F.S. The ecological significance of the herbaceous layer in temperate forest ecosystems. Bioscience 2007, 57, 845-858. [CrossRef]

33. Baselga, A. Partitioning the turnover and nestedness components of beta diversity. Glob. Ecol. Biogeogr. 2010, 19, 134-143. [CrossRef]

34. Koleff, P.; Gaston, K.J.; Lennon, J.J. Measuring beta diversity for presence-absence data. J. Anim. Ecol. 2003, 72, 367-382. [CrossRef]

35. Lennon, J.J.; Koleff, P.; Greenwood, J.J.D.; Gaston, K.J. The geographical structure of British bird distributions: Diversity, spatial turnover and scale. J. Anim. Ecol. 2001, 70, 966-979. [CrossRef]

36. Simpson, G.G. Mammals and the nature of continents. Am. J. Sci. 1943, 241, 1-31. [CrossRef]

37. Baeten, L.; Vangansbeke, P.; Hermy, M.; Peterken, G.; Vanhuyse, K.; Verheyen, K. Distinguishing between turnover and nestedness in the quantification of biotic homogenization. Biodivers. Conserv. 2012, 21, 1399-1409. [CrossRef]

38. Anderson, M.J.; Ellingsen, K.E.; McArdle, B.H. Multivariate dispersion as a measure of beta diversity. Ecol. Lett. 2006, 9, 683-693. [CrossRef] [PubMed]

39. Anderson, M.J.; Crist, T.O.; Chase, J.M.; Vellend, M. Navigating the multiple meanings of beta diversity: A roadmap for the practicing ecologist. Ecol. Lett. 2011, 14, 19-28. [CrossRef] [PubMed]

40. Austin, M.P. Use of ordination and other multivariate descriptive methods to study succession. Vegetatio 1977, 35, 165-175. [CrossRef]

41. Anderson, M.J. A new method for non-parametric multivariate analysis of variance. Aust. Ecol. 2001, 26, $32-46$.

42. Vegan: Community Ecology Package, Version 2.0.. Available online: http://CRAN.R-project.org/package= vegan (accessed on 1 October 2013).

43. Zhou, B.; Wong, W.H. A bootstrap-based non-parametric ANOVA method and its application to multi-factorial microarray data. Stat. Sin. 2011, 21, 495-514. [CrossRef]

44. R Development Core Team. R: A Language and Environment for Statistical Computing; R Foundation for Statistical Computing: Vienna, Austria, 2015. Available online: http://www.R-project.org/ (accessed on 5 October 2014). 
45. Hammer, Ø.; Harper, D.A.T.; Ryan, P.D. PAST-Paleontological statistics software package for education and data analysis. Palaeo. Electronica 2001, 4, 1-9.

46. Schmidt, W. Herb layer species as indicators of biodiversity of managed and unmanaged beech forests. For. Snow Landsc. Res. 2005, 79, 111-125.

47. Keith, S.A.; Newton, A.C.; Morecroft, M.D.; Bealey, C.E.; Bullock, J.M. Taxonomic homogenization of woodland plant communities over 70 years. Proc. R. Soc. B 2009, 276, 3539-3544. [CrossRef] [PubMed]

48. Naaf, T.; Wulf, M. Habitat specialists and generalists drive homogenization and differentiation of temperate forest plant communities at the regional scale. Biol. Conserv. 2010, 143, 848-855. [CrossRef]

49. Smart, S.M.; Thompson, K.; Marrs, R.H.; Le Duc, M.G.; Maskell, L.C.; Firbank, L.G. Biotic homogenization and changes in species diversity across human-modified ecosystems. Proc. R. Soc. B 2006, 273, 2659-2665. [CrossRef] [PubMed]

50. Durak, T.; Holeksa, J. Biotic homogenisation and differentiation along a habitat gradient resulting from the ageing of managed beech stands. For. Ecol. Manag. 2015, 351, 47-56. [CrossRef]

51. Durak, T. Changes in vegetation of fertile Carpathian beech forests with perennial honesty Lunaria rediviva based on analysis of the herb layer (Słonne Mountains, Eastern Carpathians). Sylwan 2011, 155, 120-128.

52. Durak, T. Vegetation changes in East Carpathians piedmont mixed forest under restricted forest management in "Góra Sobień" nature reserve. Sylwan 2009, 153, 627-634.

53. Turnock, D. Ecoregion-based conservation in the Carpathians and the land-use implications. Land Use Policy 2002, 19, 47-63. [CrossRef]

54. Forestry 2011; Central Statistical Office of Poland: Warszawa, Poland, 2011.

55. Mölder, A.; Bernhardt-Römermann, M.; Schmidt, W. Herb-layer diversity in deciduous forests: Raised by tree richness or beaten by beech? For. Ecol. Manag. 2008, 256, 272-281. [CrossRef]

56. Durak, T. Changes in diversity of the mountain beech forest herb layer as a function of the forest management method. For. Ecol. Manag. 2012, 276, 154-164. [CrossRef]

57. Durak, T. Long-term trends in vegetation changes of managed versus unmanaged Eastern Carpathian beech forests. For. Ecol. Manag. 2010, 260, 1333-1344. [CrossRef]

58. Harmon, M.E.; Franklin, J.F.; Swanson, F.J.; Sollins, P.; Gregory, S.V.; Lattin, J.D. Ecology of coarse woody debris in temperate ecosystems. Adv. Ecol. Res. 1986, 15, 133-302.

59. Stewart, G.H.; Burrows, L.E. Coarse woody debris in oldgrowth temperate beech (Nothofagus) forests of New Zealand. Can. J. For. Res. 1994, 24, 1989-1996. [CrossRef]

60. Winter, S.; Flade, M.; Schumacher, H.; Kerstan, E.; Möller, G. The importance of near-natural stand structures for the biocoenosis of lowland beech forests. For. Snow Landsc. Res. 2005, 79, 127-144.

61. Lombardi, F.; Lasserre, B.; Tognetti, R.; Marchetti, M. Deadwood in relation to stand management and forest type in Central Apennines (Molise, Italy). Ecosystems 2008, 11, 882-894. [CrossRef]

(C) 2015 by the authors; licensee MDPI, Basel, Switzerland. This article is an open access article distributed under the terms and conditions of the Creative Commons by Attribution (CC-BY) license (http://creativecommons.org/licenses/by/4.0/). 